\title{
Extraordinary Happenings and Ordinary Affects
}

\author{
Sabrina Lilleby \\ UNIVERSITY OF TEXAS AT AUSTIN
}

This project was undertaken during a period of excessive violence. A few years earlier, many citizens of Cairo considered artefacts of war such as tanks, machine guns, barbed wire and sandbags as belonging to a war-zone, not to their intimate cityscape. Yet, with the events that unraveled in the spring of 2011, dwellers of Cairo were tossed into a whirlwind of immediate experiences with the artefacts and acts of war. The previously mentioned items, together with explosions, check points and death sentences have now become part and parcel of the everyday for a majority of the population. Dwellers of this colossus of a city to often oscillate between glimpsing shimmers of alternative futures, and staring down dark ravines of hopelessness. However, between these intense outliers, the ordinary seem to carry on. In this paper, I suggest that although Cairenes increasingly encounter a number of extraordinary and violent events in their everyday life, these events get weaved in the fabric of everyday life and produce ordinary affects. My argument is not about apathy, nor of despair; it is not an exotic account of the other, or a subaltern tale of agency amidst misery. Instead, it is an account of the affects that circulate in an everyday that must carry on. To relay the affective, ephemeral, yet ordinary in contemporary Cairo, my paper- much inspired by Stewart (2007) - starts off with a short introduction, then recounts several short fragments. These snippets are based on number of personal experiences and stories collected in Cairo over the last five years.

\section{KEYWORDS}

Affect, Cairo, Everyday, The Urban, Violence 
I.

A winter morning, a man far away from our city searched in the back of the cabinet for some matches. Then, he lit himself on fire. They say that is when it started - this period of excessive violence. The extensive list of characteristics of living in an authoritarian regime and in a neoliberal economy daily grows longer, as the dwellers of this colossus of a city we call Cairo oscillate between glimpsing alternative futures, and staring down gorges of hopelessness. Yet, between these outliers, the ordinary carries on. In the everyday, they encounter a number of extraordinary and violent events and objects, but these get woven into the fabric of everyday life and produce ordinary affects (Stewart 2007). The sort of experiences and moods I have been trying to grapple with recently occur here, in the middle between extraordinary events and objects and ordinary affects. But, how do we write this complex and concatenated world where nothing has yet to be coalesced?

When speaking of present Cairo, we could talk of the affective modes of fear; how fear leaks into the everyday. We could talk about how fear emanates from television screens; how it creeps across the living room floor and hits bodies, seeps in and fills that void where a sense of belonging used to dwell. But, this experience is daily nourished through media representations. Instead, this is an attempt to capture something more fleeting. What happens when people do not get scared, or when fear mixes with anger, happiness or lust? How do we capture that which did not happen or that which is yet to occur? This paper is not a paper about apathy, psychological repression or of despair; it is not an exotic account of the other or a subaltern tale of agency amidst misery. Instead, it is an account of the affects that circulate in everyday, a meditation on how we live in the suspense between the ordinary and extraordinary. Instead of rendering the city as inexplicable because of this seeming contradiction, I try to hold it in tension and write it. Consequently, this is not a conventional argument, it is an experiment in thought as well as in practice; the practice of writing the sensory topography of a city.

A few years ago, despite living with a despot, many dwellers of Cairo considered artifacts such as tanks, machine guns, barbed wire and sandbags as belonging to a war-zone, not to their intimate milieu. Yet, with the events that unraveled in the spring of 2011, dwellers of Cairo were tossed into a perplexing everyday where they have gained immediate experience with the objects and acts one supposed be- 
longed to warfare. However, instead of being brought to a standstill, halted by fear, the city trudges on and the previously mentioned items, together with explosions, check points, brick walls, balaclava clad soldiers and executions have become part and parcel of the everyday. These items mix with the mundane tasks of cooking, chatting, singing, drinking, eating, fucking and crying. In subsuming these novel objects, the cadence and pulse of the ordinary skips a beat and then returns to its rhythmic beat. What happens when people are not unnerved; when the extraordinary becomes the ordinary, or when panic mixes with anger, happiness or lust? Something happens, but it cannot be properly named. It hits us more like a mood, a pressure in the atmosphere or reverberations in the ambience (Brennan 2004). In what follows below I try to relay happenings, experiences, moods and subjects before they have yet to be properly named. This is me trying to comprehend a city but also an acknowledgement that it cannot ever really be grasped.

Cairo as a space in this text takes the shape of a series of instances, stories and encounters collected from my own and my interlocutors' everyday lives over the last five years. These are mixed with references to news pieces as well as rumors or urban myths I heard often while waiting for the metro, in taxis, waiting for meetings, waiting for the doctor, waiting for the man with the stamp to return from prayer or waiting for the afternoon traffic to unknot itself. These notes are mixed with conversations I had with acquaintances and friends about one particular but extensive topic. During these talks I would offer the theme of the intermingling between the mundane and extraordinary in everyday life in Cairo. I would ask what sort of feelings, happenings, episodes and memories would offer themselves up. If I had chosen to use names when referring to my interlocutors, these would undeniably have had to be changed for security reasons. However, I opted out of using names altogether in order to relay a sense of a shared experience of the present. Stories can both be owned and shared. Anecdotes circulating in the city show how these often take on a life of their own.

Apart from the absurdity of the everyday, the themes of circulation, transmission, and movement most often turned into repeated refrains during these conversations. Much like the city's traffic, my co-conversationalists would speak of being in perpetual motion not necessarily in order to represent or to understand but merely to make ends meet. They would speak of movement without a particular goal, but still movement as an embodied everyday practice. They would speak of a life haunted by the memory of major social uprisings occurring as if out of nowhere, perhaps merely because bodies aligned themselves in productive constellations at the correct time: a shopkeeper on fire in Tunis, a young man found tortured to death at a police station in Alexandria, a son being groomed for taking over the presidential palace, and hundreds of sleeping strikers dotting the 
sidewalks of Kasr el Aini. Bodies that meet in the social, produce reverberations, affects and allies (Butler 2011). It is hard to forget or suppress that possibilities rest in their meeting, in the feeling of bumping up against each other, and the subsequent doing and acting, the touching, affecting and reshuffling (Spinoza 2002).

Daily, human life in Cairo, just like hard currency, seems to diminish in value. Then, what remains? Where do we go from here? This text provides no blueprint but the last few lines I offer up near the end gesture towards the inherent possibilities of movement as being. An inkling and hunch, nudging and whispering that potential rests somewhere in the future present (Bergson 2001). A precarious life seems to me a life fated to perpetual motion marked by continual uncertainty. As a response, we can resign in despair since this is a life other than promised by multiple modernist political projects or we can take a deep breath and look around (Tsing 2015). In a world where all we know is that we have to get up in the morning, to trudge on in a silence imposed by excessive external violence and internal apathy, the city might seem silent. However, before I move on to the next section I want to re-assert that it is precisely in the act of getting up in the morning, and the subsequent movement, where possibilities of new constellations, alignments and alliances lay.

II.

She was in a meditation class because Cairo is just the kind of city where meditation becomes appealing and necessary. During the break she couldn't reach him and thought of how he entered the apartment the day before. How he had run to the bathroom vomiting from all the teargas, heaving for his breath. The thoughts kept on seeping into her mind between the exhalations and inhalations. Breathe in. Breathe out. She checked her phone again. A message from him that read "hey can we skype. my phone is dead... by the way i got shot but i'm doing fine." On Skype, she sees that his face is distorted from one of the thirty pellets that had permeated his body. His mom appears on the screen. She is making him tea and gathering the laundry.

One day, two years later, she walks down the same street where he was shot. A graffiti artist has painted a large mural on a wall. It depicts an enormous lifelike heart on a blood-red and orange background, and a speech bobble that states, 
"hope". Someone else has hurriedly written in answer, "fuck you and fuck your hope- we are living in a counter-revolution". The state has set up traffic lights on that street. Waiting at the red light, pedestrians and drivers alike move through a gallery of murals memorializing the bloodshed from two years past.

Around the same time as he got shot, young cosmopolitan Cairenes met on a beach in the very south of Egypt to dance and drink- a sort of Egyptian Woodstock if you will. This year, the organizers decided it was too dangerous to have the festival on an open beach and chose to move it to one of the gated resorts up the coast. She and her husband were now sitting in their bedroom talking about the festival. They were mocking the cowardly upper class youth that didn't dare to move out of their comfort zone. Then, they heard the boom and felt the shock; the windows reverberated from the tremor of the bomb. Fear filled her as she called her friend who was walking her dog. No, not to worry, she said. Apparently it was just a bomb at the church two streets down and nobody had gotten hurt.

Nobody knew who put it there. But again, that was also before some young techie developed an app that could tell the location of bombs around town. She avoided the metro that day and got in a cab to go to her weekly writing group. They had started without her. One of the group members was from Beirut, and had already lived through two civil wars- she smiled understandingly and continued sharing her text with the group.

She had been walking her dog with another Lebanese friend a few weeks earlier. As they strolled through an empty desert valley just outside of Cairo, with the little white and fluffy dog playing among the rocks, they heard the sound of military aircrafts sear through the sky. Her friend gasped in fear. It reminded her of a dream from the night before, itself an echo of a real life nightmare twenty years earlier. She told her friend about one night when she was eight. She had asked her mom, "What is that sound?" and her mom answered, "Hush, keep practicing for your math test." The next morning, she passed her math exam with excellence; but over thirty people had died from the bombs the night before. Temporarily drawn lines between past and present, and, between childhood and adulthood blur. The celebration of life intermingles with the mourning of the dead.

After visiting a friend who had just given birth, she walked down the street of a posh neighborhood when she saw the beautiful flowers between two embassy buildings. The man selling the flowers was wearing a long traditional garb and would not have fit into the sumptuous neighborhood had it not been for the inexpensive, yet exquisite, flowers he was selling. Suddenly she heard one of the soldiers guarding an embassy yelling, "run, run". She catches the sound of an 
empty machine gun going off. Tac tac. Some soldiers run. She is filled with terror and wants to run, but calls, "What? What is that?" to the old man selling flowers. He responds, "no problem, no problem," but she starts moving fast in the opposite direction. Then the soldiers all start laughing. It is a game. They were bored.

Boredom is all too familiar to anyone living in a megapolis. Everyone and their grandmother spend hours commuting in the overcrowded traffic. Someone tells her about their bus ride home from work. Halfway home, the bus came to a stop. The passengers, tired from a long day of labor and eager to return home for dinner, looked up annoyed as the bus came to a halt. Terrified faces attached to rapidly moving bodies started running from the large stadium towards the bus. But the vehicle moved on. The workers had to get home for dinner. Later, they read in the newspaper that some of the commuters had not gone home for dinner. Instead, they had gotten out of their car and beat up one of the fleeing football fans in true vigilante fashion. The people, and that thing we call the state, merge in the social life of Cairo. And since the army officially took over, its chorus has been the constant repetition of two words, "Terror and Security, Security and Terror."

Strangely though, statistics show that the most dangerous everyday activity is crossing the street. You regularly observe individuals driving down the wrong lane on the highway dauntingly facing the ongoing traffic. Their kid is hanging out of the window, sucking in the wind, while they listen to the hourly news broadcast announcing that the latest patriarch has declared a state of emergency. The driver and his kid feel comforted. They can get home before the rush hour begins.

Sometimes that which we want the most is what actually creates the opposite. Not only does the attempt to make everything coherent impede our actual understanding, but our quest for security leads to insecurity. A sudden surge occurs in the incarceration of protesters, gays, communists, islamists, terrorists, doctors, professors, poets and NGO workers. Simultaneously, jokes are produced at an intensive speed. The state, its oppression, and the reactions to it, provides enough material for a proverbial fountain of jokes. One day, some of the hordes of political prisoners were finally released on bail. But, it was not only prisoners who came out of the prison gates. Together with the detainees came a flock of ostriches. Rumor has it that you can only be served ostrich eggs at upscale hotels dotting the banks of the Nile - the Mariott, the Hilton, the Four Seasons, the Hyatt Regency- but apparently you can breed them in jail. 
You can incarcerate a person - even an ostrich - but you cannot incarcerate a joke. A joke might surface amidst a crammed group of passengers stuck in a minivan during a traffic jam, but it travels faster than the small white buses dotting the highway. It rolls down the street like an avalanche taking down everyone in its path. It lays bare the ridiculousness and absurdity of imminent precarity in the same way as cries from protesters who confront power and capital. But that was before they went to jail.

Somehow it has been forgotten that initially people were rioting about the lack of bread and the lack of healthcare. This goal is only recalled in rare glimpses. Such a glimpse occurred when they went to the fancy private hospital to do a biopsy, and gave the doctor his money in a white, unmarked envelope over the surgery table. Kidneys are traded like fresh beans at the market; like pellets from a rifle. While among those who used to protest, casings from the pellets become memorabilia- a nostalgia of the time they still dared to take to the street to protest the fact that some people cannot own their own kidneys. Sometimes the bullet hits, sometimes it does not reach the target.

It is an ardent task tracing the lines of flight of bodies that meet in the social. More often than we would like to admit, happenings can be attributed to mere chance. The image that spurred the affective avalanche that was to come, was of a man hundreds of kilometers away who was driven to the edge of sanity and lit himself on fire. Or, was he the mad one? When your entire social world seemingly pretends like nothing even happened, or is happening - getting out the matchbox does seem mundane, yet powerfully lucid.

Those with a penchant for psychoanalysis like to attribute madness to the suffering of the past, but what about the trauma of the present? In Cairo's alternative health centers who cater to thick wallets, practitioners speak about the important link between diet and mental health. They do not speak about how the lack of a diet, and the daily struggle for food affects one's sanity.

Yet, although madness becomes ordinary, the city is suspended in perpetual motion, moving around, making ends meet. Life does not stop because it cannot stop. The labor of worlding trudges on. The new minister of justice told us that," We are the masters and the rest are the slaves", but a cabdriver says, "They don't know our anger, no one can tell the future except God". 
The multitudes oscillate between motion and rest. Sometimes the motion accelerates and comes to exceed that which was previously imagined. The unthought-of and unspoken gets articulated. Masses of singularities transform into a dangerous wave- a maelstrom of affinity that can only be intersected by a red wave. Then, they are slaughtered by the hundreds.

He was working as a video journalist at the time of the massacre, and his boss had sent him to the large mosque where they kept the bodies, to videotape the scene. On the steps of the mosque - turned morgue- hundreds of people had crowded together pushing towards the doors of god's house. The smell of the sweat from victims' family members mixed with the odors of journalists and other voyeurs. It was perhaps even worse than the smell of the 700 bodies on the floor inside. Without luck, he pushed and he pushed to get inside to capture those bodies on two minutes of film in order to keep his job. Then a new group of mourners arrived, carrying yet another dead body, and the doors of the building shot open. He grabbed on to the side of the body, starting to carry it- his role in the scene seemingly changing from journalist to mourner. When he came inside, he looked around. The mass of dead bodies moved him into silence. He captured the scene on camera, but it took six more months before he would speak of that unspeakable scene.

After the massacre, they fought over being the divine's mouthpiece on this plane of existence. In numerous apartments around the city, humans cohabitate with the jinn. When an otherworldly creature refuses to acknowledge that the curtain between our world and their world should remain closed, you call the priest or the sheikh who will exorcise the specter. If they cannot come, you play religious CDs of holy texts. A jinn is real, but 700 dead bodies, 700 entire life stories, fall prey to collective amnesia. But, in our world not only humans are actors. Absence, or utter silence itself, becomes the strongest actor of all. It simmers and reverberates under our streets, under our skin, in our guts, until one day it bursts, and the silence becomes so loud that it turns to noise. And another man searches in the back of the cabinet for the matches and lights himself on fire. His image affects us, and once again, the silence is broken. 


\section{References}

Agamben, G. (1998). Homo Sacer: Sovereign Power and Bare Life. Stanford: Stanford University Press.

Amar, P. (2006). Cairo Cosmopolitan: Politics, Culture, and Urban Space in the New Globalized Middle East. Cairo: American University in Cairo Press.

Bergson, H. (2001). Time and Free Will: An Essay on the Immediate Data of Consciousness. Mineola, N.Y: Dover Publications.

Berlant, L. (2011). Cruel Optimism. Durham \& London: Duke University Press. Brennan, T. (2014). The Transmission of Affect. Ithaca \& London: Cornell University Press.

Butler, J. (2011). Bodies in Alliance and the Politics of the Street. Lecture.

Casarino, C. (2011). Marx before Spinoza: Notes toward an Investigation. In: D. Vardoulakis, ed., Spinoza Now, 1st ed. London: University of Minnesota Press, pp.179-236.

Certeau, M. de. (2011). The Practice of Everyday Life. Oakland: University of California Press.

Das, V. (2007). Life and Words: Violence and the Descent Into the Ordinary. Oakland: University of California Press.

Deleuze, G. and Guattari, F. (2001). Thousand Plateaus. London \& New York: Continuum.

Elyachar, J. (2010). Phatic labor, infrastructure, and the question of empowerment in Cairo. American Ethnologist, 37 (3), pp.452-464.

Foucault, M. (1997). Ethics: Subjectivity and Truth. New York: New Press.

Latour, B. (2007). Reassembling the Social: An Introduction to Actor-NetworkTheory. Oxford: Oxford University Press.

Law, J. (2004). After Method: Mess in Social Science Research. New York \& London: Routledge.

Marx, K. (1994). The Eighteenth Brumaire of Louis Bonaparte. New York: International Publishers.

Navaro-Yashin, Y. (2002). Faces of the State: Secularism and Public Life in Turkey. Princeton: Princeton University Press. 
Papadopoulos, D., Stephenson, N. and Tsianos, V. (2008). Escape routes: control and subversion in the twenty-first century. London \& Ann Arbor: Pluto Press.

Seigworth, G.J. and Gregg, M. (2010). An Inventory of Shimmers. In: The Affect Theory Reader. Gregg, M. and Seigworth, G.J ed, 1st ed. Durham \& London: Duke University Press, pp.1-29.

Spinoza, B (2002). The Ethics. In: The Complete Works. Shirley, S. and Morgan, M.L., ed. 1st ed. Indianapolis: Hackett Publishing, pp.213-382.

Stewart, K. (2007). Ordinary Affects. Durham \& London: Duke University Press. Stewart, K. (2010). Worlding Refrains. In: M. Gregg and G.J. Seigworth, eds. The Affect Theory Reader, 1st ed. Durham \& London: Duke University Press, pp.339-355.

Tsing, A.L. (2015). The Mushroom at the End of the World: On the Possibility of Life in Capitalist Ruins. Princeton: Princeton University Press. 